\title{
Initiatives to integrate operational knowledge in design: a building client perspective
}

\author{
Rasmussen, Helle Lohmann; Jensen, Per Anker; Nielsen, Susanne Balslev; Kristiansen, Anders Højen
}

Published in:

Facilities

Link to article, DOI:

10.1108/F-02-2017-0021

Publication date:

2019

Document Version

Peer reviewed version

Link back to DTU Orbit

Citation (APA):

Rasmussen, H. L., Jensen, P. A., Nielsen, S. B., \& Kristiansen, A. H. (2019). Initiatives to integrate operational knowledge in design: a building client perspective. Facilities, 37(11-12), 799-812. https://doi.org/10.1108/F-022017-0021

\section{General rights}

Copyright and moral rights for the publications made accessible in the public portal are retained by the authors and/or other copyright owners and it is a condition of accessing publications that users recognise and abide by the legal requirements associated with these rights.

- Users may download and print one copy of any publication from the public portal for the purpose of private study or research.

- You may not further distribute the material or use it for any profit-making activity or commercial gain

- You may freely distribute the URL identifying the publication in the public portal 
Post print version of: Rasmussen, H., Jensen, P., Nielsen, S. and Kristiansen, A. (2019), "Initiatives to integrate operational knowledge in design: a building client perspective", Facilities, Vol. 37 No. 11/12, pp. 799-812. https://doi-org.proxy.findit.dtu.dk/10.1108/F-02-2017-0021

\title{
Initiatives to integrate operational knowledge in design: a building client perspective
}

Helle Lohmann Rasmussen (Department of Management Engineering, Technical University of Denmark, Lyngby, Denmark)

Per Anker Jensen (Department of Management Engineering, Technical University of Denmark, Lyngby, Denmark)

Susanne Balslev Nielsen (Oslo Metropolitan University, Oslo Business School, Oslo, Norway) Anders Højen Kristiansen (NNE A/S, Copenhagen, Denmark)

\begin{abstract}
Purpose: This paper aims to focus on deliberate actions by the building client to integrate knowledge of facilities management, in particular building operation, in design and construction of sustainable facilities. Examples of current practices are studied to answer the questions: Which initiatives to enable operational friendly and sustainable buildings are currently used by building clients in Denmark, which initiatives could be appropriate to use in the future, and which parties are in the best position to implement the various initiatives?
\end{abstract}

Design/methodology/approach: The study is a hermeneutic multi-method study, which consists of a review of former research, a case study and a survey. It starts with theoretical background based on earlier research with the aim to identify initiatives to ensure the use of operational knowledge in building design. Hereafter the paper present, analyse and discuss two studies: A case study of current practices at a university campus organisation and a survey of five swimming facilities. All cases are from Denmark.

Findings: 31 initiatives to enable use of operational knowledge in building design were initially identified. In the case study, 11 additional initiatives were found. The case study and the survey of swimming facilities show different degrees of implementation, varying from 18 to 31 initiatives implemented. However, the studies show that introducing the initiatives is not sufficient; it takes deliberate actions to get the initiatives well implemented. Within the building client organization, three main actors should care for implementing the initiatives: Top management, Building client division and Operation division.

Originality/value: Research-based literature on practices in relation to knowledge transfer from operation to design is limited. This paper provides insights into deliberate efforts on transferring knowledge from operation to design among Danish building clients.

Keywords: Sustainability, Facilities management, Energy efficiency, Knowledge transfer, Building design, Performance gap. 


\section{Introduction}

A large number of newly built facilities do not live up to the expected performance at the time they are taken into use (Due and Stephensen, 2012; Hansen and Damgaard, 2012). In concerns of energy consumption, the literature describes a reliability gap between the calculated and the actual energy consumption (Wilde, 2014; Corry, 2015; Way and Bordass, 2005; Ornetzer et al., 2016). In addition to energy efficiency, other aspects of building performance have been recognized to be deficient: lack of functionality, poor indoor climate, difficulties in operation and maintenance, and poor cleaning possibilities. In other words, there is a gap between expected and actual performance, and in a broad perspective.

The reduced performance in facility operation persists until changes can be administered, though some deficiencies are likely to be permanent once the facility is in operation. Changes may consist of adjustment or replacement of parts of the technical installations, physical changes or addition in construction, and/or changes in human behaviour.

This research is based on the assumption that knowledge transfer from facilities management to design can reduce the gap between expected performance and actual performance in use. Not only will this lead to better predictions of operation and maintenance budgets, needed staff, environmental impact etc. The operational knowledge is needed for quality assessment throughout the construction projects and will reduce some of the risks associated with investments in new complex facilities like universities, swimming facilities and hospitals. The research points to the need of mobilising facilities management (FM) knowledge to ensure that knowledge and experience from existing buildings is fed into the design and construction of new buildings (Hansen and Damgaard, 2012; Alhaji Mohammed and Hassanain, 2010; Ganisen et al., 2015). Studies have concluded that FM should contribute in different phases of design and construction (Jensen, 2008; Jensen 2012; Due and Stephensen, 2012), and have emphasized the need for the individuals, who will operate the facility, to be involved in the briefing stage (Way and Bordass, 2006). Galamba and Nielsen (2016) focus on the need for building organisational capabilities for sustainable facilities management and point to new ways of collaborating to combine the insights from building design and operation. Chew et al (2017) highlights the importance of integrating "green maintainability" and "green FM" right from the planning and design stage to ensure the actual sustainability of a new facility.

Previous studies assigns FM a quite noble role in the planning and design stage, contributing with knowledge on a variety of issues (Erdener, 2003; Alhaji Mohammed \& Hassanain, 2010; Ganisen et al., 2015). This paper investigates the issue from a practitioner's point of view, offering insight on available practical implementable initiatives to integrate FM knowledge in design, and gives examples on the level of implementation of these initiatives in Denmark. The paper investigates how integration of operational knowledge in building design is currently done in practise in the Danish building industry with particular focus on which initiatives are being used by building clients. This is based on previous research's identification of the building client as the most important actor to ensure integration of FM knowledge in new building projects (Jensen, 2009). The role of other actors should not be understated, and we recommend future research to investigate the initiatives and possibilities of e.g. designers to ensure FM integration in design.

Faulty design is by researchers identified as one of the main reasons for poor maintainability and lack of operational friendliness (Chew, 2017; Alhaji Mohammed \& Hassanain, 2010). The scope of this paper is limited to initiatives in the planning and early design stage. Additional initiatives are important in later stages 
and in particular, when the facility is handed over to the building client and operation begin, but this is not included in this paper.

\section{Methodology}

The overall research paradigm is characterised as pragmatism (Saunders et al., 2009) as it applies a practical approach, integrating different perspectives to help collect and interpret data. The research design is a hermeneutic, multi-method approach consisting of three phases:

1. A review of former research to identify practical initiatives (also named methods or tools) mentioned in the literature for ensuring operational knowledge in building processes.

2. An explorative case study investigating if the recommended initiatives from the literature are used in practice. The case organisation was DTU Campus Service, who owns and operates the university facilities for the Technical University of Denmark. This case study focuses on the collaboration between the internal divisions involved in building projects by asking, if and how the initiatives identified in the previous phase were in use. The case selection was based on a preference of best practices in a Danish context, the choice of an in-house real estate and facilities management organisation with a common strategic context and access to qualitative data about practices of collaboration between design teams and operation and maintenance teams. The study identified additional initiatives, which were not revealed in the literature.

3. A survey of the construction management processes regarding recent swimming facilities in Denmark. The aim was to investigate, if the initiatives from the literature were used in public construction projects and swimming facilities were chosen as they are particular energy consuming and inappropriate design solutions are likely to be costly in the operational phase. The survey asked similar questions as the previous case study and also collected data to be used for benchmarking energy consumption to investigate, if it was possible to document a relation between the use of initiatives in the building projects and the observed building performance once in use. The survey has replies regarding 5 Danish Swimming facilities of 1-10 years of operation.

The case study was conducted in 2013 and the survey was conducted in 2015. More information about the investigated facilities and the data collections is provided in the sections later in the paper, where the findings of each study are presented.

The strength of the methodological approach is the identification of various initiatives that building clients can take to facilitate the integration of operational knowledge in the early design of construction projects. However the explorative character of current practices at the time of study is limited in terms of measuring the actual effect of each initiative.

\section{Theoretical background}

The building industry is characterized as a project-based industry and because of that, there is a limited degree of learning from experiences of use and operation of existing buildings. (Lê, 2007; Meng, 2013). 
Development of professional FM can be seen as the missing link to bridge the gap between building operation and building design (Jensen, 2009; Meng, 2013).

Over the years, there have been some development and research activities that focus on increasing knowledge transfer from building operation to building design and construction. As early as 1985 The Danish Building Development Council published a recommendation for planning operational friendly buildings (BUR, 1985) and in 2000 the British Building Research Establishment published a report commissioned by the British Institute of Facilities Management (BIFM) about applying facilities expertise in building design (Jaunzens et al., 2001).

The idea of knowledge transfer from building operation to building design is not new. Bröchner (1996) reports experiments from Sweden in the 1960's, but these were less than satisfactory. Bröchner makes a reevaluation based on expectations that the development in information technology should have made the knowledge transfer easier in the mid 1990's, but concludes that the necessary incentives were lacking. However, Bröchner is concerned with the feedback from building operation of a building to the design team responsible for designing that particular building. In contrast, this paper is concerned with feed-forward from building operation of existing buildings to the design and construction of new buildings.

Recent studies (Kalantari et al., 2017) concludes that in spite of researchers efforts on the topic, there still is a lack of practical recommendations on organization, culture and communication between FM and building project teams. Other studies highlights that IT software and building and design automation will be key elements to close the gap between calculated and actual performance (Corry, 2015; Göcer, 2015; Menezes et al., 2012). Our research focuses on the available ready-to-use initiatives and the implementation of them.

There are many aspects of FM knowledge that ought to be transferred to building projects. In this paper the main focus is on knowledge concerning operation and maintenance. The purpose of transferring knowledge about operation and maintenance to building projects is in general to ensure one gets a new building, that it easy and affordable to operate and maintain, with a good indoor environment, and has a low energy consumption and climate impact.

The research is based on, and a continuation of, former research conducted over the last decade in Denmark by different researchers. Both the case study and the survey presented in the paper are based on a number of concepts or initiatives to support transfer of knowledge from operation of existing buildings to the design and construction of new buildings. From the former research, 31 initiatives were identified as shown in Table 1. The following description will focus on the basis and sources for these initiatives. For broader literature reviews we refer to Jensen (2009 and 2012) and Zuo et al. (2013). This study did not apply one specific model of knowledge transfer as it was an inductive research exploring which initiatives are used for transferring knowledge in practice. The term 'initiative' covers tools, concepts, and tasks that are recommended in literature to be used by the building client in the early stages of design of a new facility.

\begin{tabular}{|ll|l|}
\hline No. & Initiative & Source \\
\hline 1 & Continuous briefing & \\
2 & Detailed building brief & \\
\cline { 1 - 2 } &
\end{tabular}




\begin{tabular}{|c|c|c|}
\hline $\begin{array}{l}3 \\
4 \\
5 \\
6 \\
7\end{array}$ & $\begin{array}{l}\text { Project review internally/externally } \\
\text { Public Private Partnership (PPP) } \\
\text { Contractor responsibility for operation and maintenance } \\
\text { Continuous commissioning } \\
\text { Technical Due Diligence }\end{array}$ & $\begin{array}{l}\text { Jensen } \\
(2009 \text { and } \\
\text { 2012) }\end{array}$ \\
\hline 9 & $\begin{array}{l}\text { Plan for when and how the right competences should be involved in the project to include } \\
\text { operational knowledge in the project } \\
\text { Prepare guidelines and standards for building projects }\end{array}$ & $\begin{array}{l}\text { Due and } \\
\text { Stephen- } \\
\text { sen }\end{array}$ \\
\hline 10 & Use of Life Cycle Cost assessments & (2011) and \\
\hline 11 & $\begin{array}{l}\text { Demands of accessibility to building parts (when conducting service, cleaning and } \\
\text { replacement, etc.) }\end{array}$ & $\begin{array}{l}\text { Værdibyg } \\
\text { (ValueBuil }\end{array}$ \\
\hline 12 & Demand of availability of technical assistive technology & \\
\hline 13 & $\begin{array}{l}\text { Demands about work environment when dealing with methods and materials to cleaning } \\
\text { and maintenance }\end{array}$ & \\
\hline 14 & Demand of storage and workshop facilities & \\
\hline 15 & Demands of preparation of operational plan and operation budget & \\
\hline 16 & Demands of involvement of the operational organisation throughout the building project & \\
\hline 17 & Demands of operation and maintenance documentation and instructions & \\
\hline 18 & $\begin{array}{l}\text { Demands of information and education of the operational organisation and possibly the } \\
\text { users }\end{array}$ & \\
\hline 19 & $\begin{array}{l}\text { Demand of evaluation of consequences of significant changes during the design phase on } \\
\text { operational friendliness, energy efficiency etc. }\end{array}$ & \\
\hline 20 & $\begin{array}{l}\text { Demand of evaluation of consequences of significant changes during the construction } \\
\text { phase on operational friendliness, energy efficiency etc. }\end{array}$ & \\
\hline 21 & Specific demands to the operational organisations role in starting up the operation & \\
\hline 22 & $\begin{array}{l}\text { Demands about adaptation and flexibility to changing uses, including possibility to re- } \\
\text { disposition and installation changes with least possible constructional intervention }\end{array}$ & $\begin{array}{l}\text { Jensen } \\
(2002\end{array}$ \\
\hline 23 & $\begin{array}{l}\text { Demands of appropriate infrastructure with central location of internal service functions } \\
\text { and good internal transport routes }\end{array}$ & $\begin{array}{l}2009 \text { and } \\
2011)\end{array}$ \\
\hline 24 & $\begin{array}{l}\text { Demand of minimizing the energy and resource consumption (electricity, heating, cooling, } \\
\text { water etc.) and environmental impacts }\end{array}$ & \\
\hline 25 & Demand of good indoor climate and work environment with good control possibilities & \\
\hline 26 & $\begin{array}{l}\text { Demand of maintenance friendliness the building and surrounding areas and good } \\
\text { possibilities for servicing technical installations }\end{array}$ & \\
\hline 27 & $\begin{array}{l}\text { Demands of dirt absorbing access roads and cleaning friendly surfaces both indoor and } \\
\text { outdoor }\end{array}$ & \\
\hline 28 & $\begin{array}{l}\text { Demands of durable and easy changeable construction components and materials, } \\
\text { including possibilities to reuse building parts }\end{array}$ & \\
\hline 29 & Demands of safety and security of the building, persons and assets & \\
\hline 30 & Demands of space and transportation options for waste handling & \\
\hline 31 & Demand of reasonable degree of building automation and operational monitoring & \\
\hline
\end{tabular}

Table 1: Initiatives to support knowledge transfer from building operation to building projects

Initiatives 1-7 in table 1 are based on a typology of knowledge transfer mechanisms from FM to building design and construction. The first part of the typology was initially presented in a journal article (Jensen, 
2009). It consists of a two by two matrix with on one side knowledge push from FM - based either on competences (direct involvement) or codification of knowledge - or on the other side knowledge pull from building design - based either on awareness or power. This resulted in initiatives 1-3 and a fourth about regulation, either in terms of requirements from the public or from the building client. An example used in Jensen (2009) is that the Danish state requires public building clients to make Life Cycle Cost assessment. The mechanisms with regulation is left out of Table 1, because use of life cycle cost assessments are included as initiative 10. The typology was further developed in another journal article (Jensen, 2012). The initial typology was supplemented by another two by two matrix with on one side knowledge pull from FM in terms of validation of performance - based either on integration (direct involvement) or outsourcing - or on the other side knowledge pull from building construction - based either on control or responsibility. The mechanisms with knowledge push from FM in terms of setting requirements for design was termed front end knowledge transfer and the mechanisms with knowledge pull from FM in terms of validation of requirements was termed back end knowledge transfer.

Initiatives 8-22 were developed during a best practice project conducted alongside an action research project concerning the planning of a new university building. The best practice project was based on a row of workshops involving a group of 18 FM practitioners and two facilitators. This project resulted in a Best Practice Guide in Danish (Due and Stephensen, 2012), which was further developed and published as one of many guidelines from the Danish cooperative organisation ValueBuild - initially in Danish (Værdibyg, 2013), but the guideline is in the process of being translated to English (see http://www.vaerdibyg.dk). It appears here in the author's own translation.

Initiatives 22-31 are from Jensen (2002, 2009 and 2011) which refer a study of research, development and literature concerning FM and briefing for building projects.

The accumulating 31 initiatives support the two different types of knowledge; explicit and tacit, or both. They support knowledge push as well as knowledge pull, and knowledge transfer from front end as well as from back end. The following section will show the results of investigating the use of the initiative in the case study and the survey.

\section{The case study of DTU Campus Service}

\section{Introducing the case}

The Technical University of Denmark (DTU) is located on several sites, including the main campus $12 \mathrm{~km}$ north of Copenhagen in Lyngby. Lyngby Campus is intensively increasing in the years 2010-2020 holding a construction budget of more than DKK 5 billion (roughly Euro 700,000). A technical university is characterized as being a so-called "wet" university with many laboratories and other highly specialised and complex technical systems. This means that the facilities are relatively expensive and complicated both to build and to operate. DTU Campus Service is the FM department of the university, including an Operation division and a Building client division, employing in total 215 people (2015). DTU Campus Service thereby has a considerable internal knowledge of building operation and a strategy for operational friendly and sustainable buildings. 


\section{Interviews and document analysis}

The study included three face-to-face interviews, two of them were individual interviews and one was a small focus group interview with two interviewees. The face-to-face interviews were supplemented with two interviews by mail. Furthermore, building briefs of two recent building projects were analysed.

Interviews with the Building Client division and the Operation division maps the degree of implementation of the 31 initiatives presented in theory section. Analysis of building briefs allows a systematic examination of which of the 31 initiatives are included in the building project already in early design phases. The result is a state-of-the-art of which initiatives DTU Campus Service have implemented in early design phases to ensure integration of knowledge from operation to new building projects.

As mentioned, two of the interviews, one in each of the two divisions, were conducted with cardboards cards as an artefact, each with one of the 31 initiatives written on it, see Figure 1. The interviewer handed the interviewees the cards one at a time, allowing time to talk about the use of the initiative. The interviewees were asked to place the cardboard cards one at the time under the headlines: "Implemented" or "not implemented". During the first interview, two other headlines were added: "Limited implemented" and "Planned to be implemented soon" on the proposal of the interviewee. In the Building Client division, two experienced project managers were interviewed with cardboard cards in a small focus group interview. Operation division is subdivided into smaller sections, and the manager of one of these sections were interviewed with cardboard cards. Furthermore, the head of the Operation division were interviewed. Table 1 was presented to additionally two employees of Operation division for validation. The validation was done by mail.

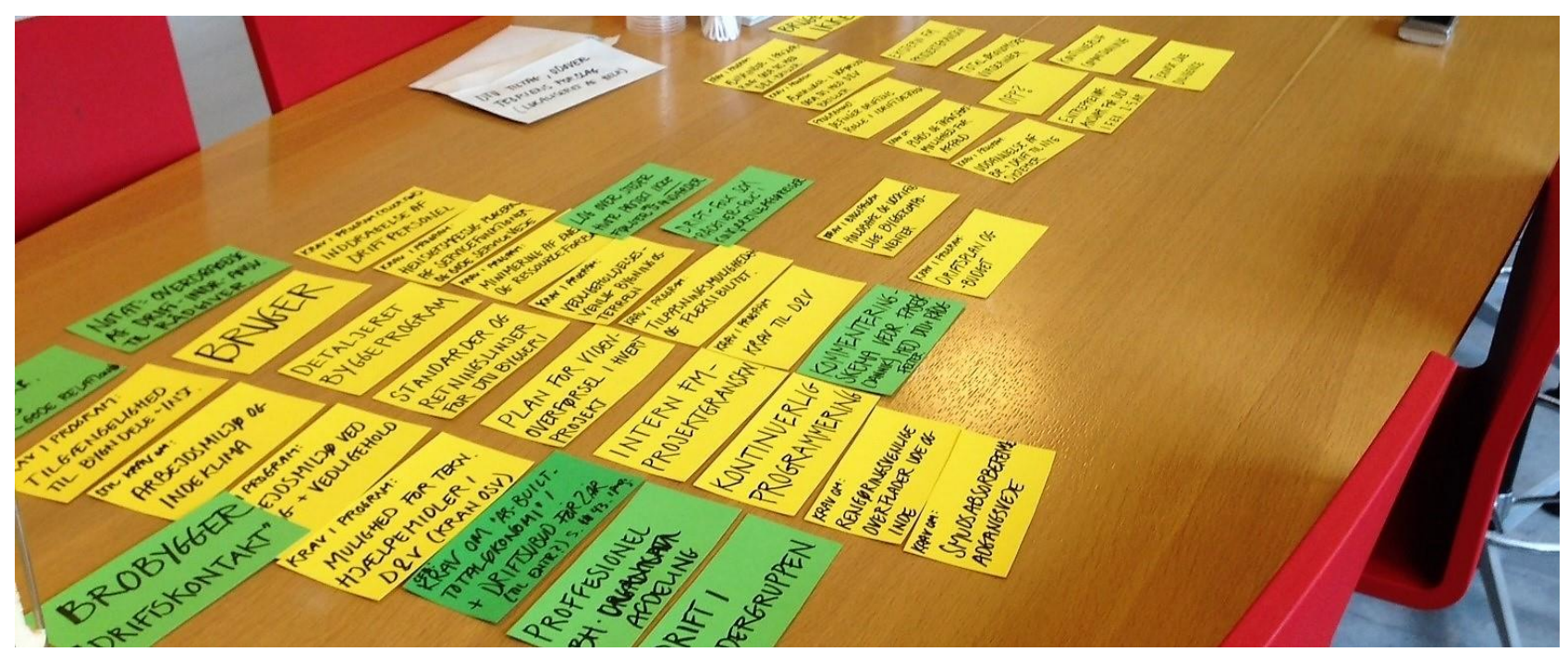

Figure 1. Examples of cardboard cards with the 31 initiatives used during interviews

Findings of the case study of Campus Service. 
The case study shows that a large number of the 31 initiatives were implemented in DTU Campus Service. Furthermore, initiatives not found in the literature review were also used, and initiatives not described by literature occurred during the interviews, when obstacles and the importance of cooperation were discussed with the interviewees. Table 2 shows the additional 11 initiatives identified with the interviewees during the cardboard card interviews.

\begin{tabular}{|ll|l|}
\hline No. & Initiative & Source \\
\hline 32 & Clear statement that operational friendly buildings are a high priority & Campus \\
33 & $\begin{array}{l}\text { One-point access in Operation Division (A bridger; person between building client } \\
\text { division and operation client division) }\end{array}$ & Service, DTU \\
34 & Establish a professional building client/construction management division \\
35 & Operations represented in management group & \\
36 & FM considered a strategic discipline & \\
37 & Care for good relations between Building Client Division and Operation Division \\
38 & $\begin{array}{l}\text { Demands on Life cycle cost analysis of the project as built } \\
39\end{array}$ & Log deviations from the guidelines and standards for building projects (see initiative 9, \\
& table 1) & \\
40 & $\begin{array}{l}\text { Agreements on how and what is included in internally reviews conducted by the } \\
\text { operational staff }\end{array}$ & \\
41 & $\begin{array}{l}\text { Establish a safety net to secure considerations of comments, demands and ideas } \\
\text { mentioned in wrong phases }\end{array}$ \\
42 & $\begin{array}{l}\text { Care for good relations between design team, construction team and Operations } \\
\text { Division }\end{array}$ & \\
\hline
\end{tabular}

Table 2: Additional initiatives by DTU Campus Service

Eighteen of the now $42(31+11)$ initiatives were categorized as well implemented in DTU Campus Service. Well-implemented initiatives assumable have a positive effect on the performance of the new facility. These 18 initiatives are included in most building project in DTU Campus Service, and the interviewees describe these initiatives as "good initiatives". Examples are detailed building brief (2), demands on good indoor climate and work environment (25) and demands on energy efficiency (24). The other well-implemented initiatives were $1,8,11,12,13,14,16,22,23,29,31,34,35,36$ and 37.

Fourteen of the 42 initiatives were categorized as only limited implemented, and are only used in some of the building projects in Campus Service. The interviewees describe obstacles and frustration with these initiatives and they appear to be unnecessarily resource intensive in their current level of implementation. Examples of limited implemented initiatives are written guidelines and standards for new facilities (9), internal project review (3), demands of operation and maintenance material (17) and Life Cycle Cost assessments (10). Other limited implemented initiatives were 15, 18, 26, 27, 28, 32, 33, 38, 40 and 42.

Five initiatives $(6,7,21,39$ and 41$)$ were, according to the interviewees, planned to be implemented soon, including building commissioning. The other five initiatives $(4,5,19,20$ and 30) were either not known or for various reasons not implemented, including contractor responsibility for operation and maintenance (5). 


\section{The survey of five swimming facilities}

The questionnaire survey covered five public swimming facilities from five different municipalities in Denmark. Swimming facilities have a high degree of technical complexity, particularly in terms of water treatment with purification systems that need to be operated competently and carefully to prevent health problems among the guests. Because of that, one needs to pass a special course to be responsible for operating swimming facilities In Denmark. The respondents were all responsible for operation of the swimming facilities. The criteria for selecting the facilities included that they were constructed or refurbished within the last 10 years to make it likely that information from the building project was in the memory of the respondents.

The questionnaire focussed on two issues. Firstly, what initiatives to transfer operational knowledge into construction had been used and with how good an effect according to the perception of the respondents. Secondly, what was the energy consumption in terms of electricity, water and heating. Besides, the questionnaire included basic data about the swimming facilities like number of $\mathrm{m}^{2}$ and guests to allow calculation of key indicators for benchmarking. The results of the second part is not included in this paper as it did not lead to any clear conclusions.

The main results for the first issue are shown in Figure 2. For each of the 31 initiatives presented in the theory section it includes information for how many of the swimming facilities the initiative was used with good effect, with limited effect, not used, or use not known by the respondents. All initiatives were used in at least two of the five facilities. Initiative 11 concerning "Demands for accessibility to building parts" was used the most with good effect - in three facilities. Five other initiatives $(15,17,23,29$ and 30) were used with good effect in two facilities. Eleven initiatives were used only with limited effect or not used. Used with limited effect was the largest category with 84 answers, used with good effect was the smallest with 27 answers, not used or not known together had 44 answers. 


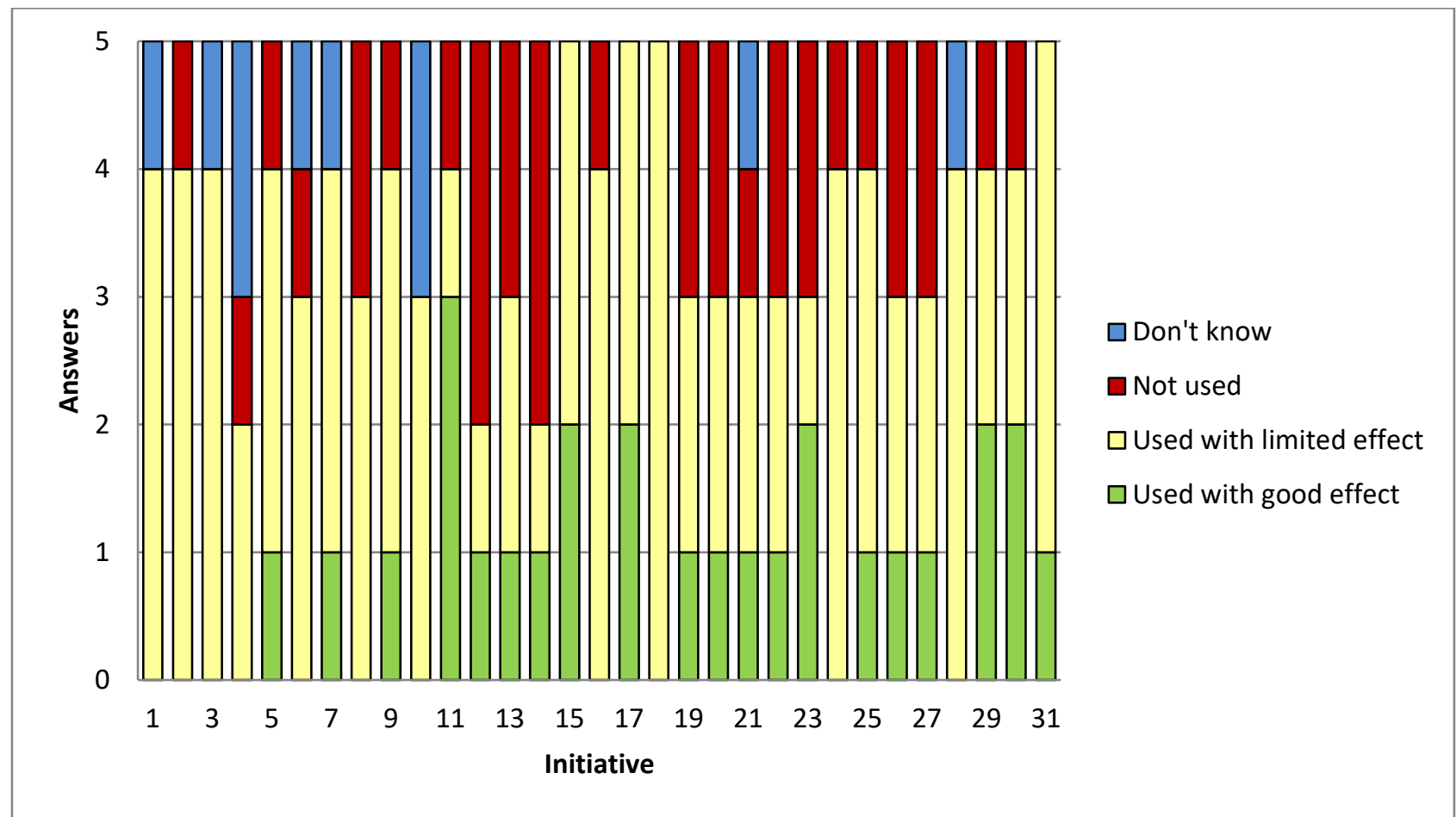

Figure 2. Initiatives used in five swimming facilities (graphical overview of answers)

\section{Analysis}

\section{Who should care?}

The literature review identified 31 initiatives. The case study of Campus Service added 11 initiatives, thus 42 initiatives in total. The main responsible to take care of the use and thereby ensuring the benefits of the initiatives is the building client or owner. Besides private housing, a building client is rarely a single person but an organisation of some kind and this blurs the otherwise clear statement of responsibility. The building client in both the swimming facilities and Campus Service consist of three main parties involved in the building projects, illustrated by Figure 4 .

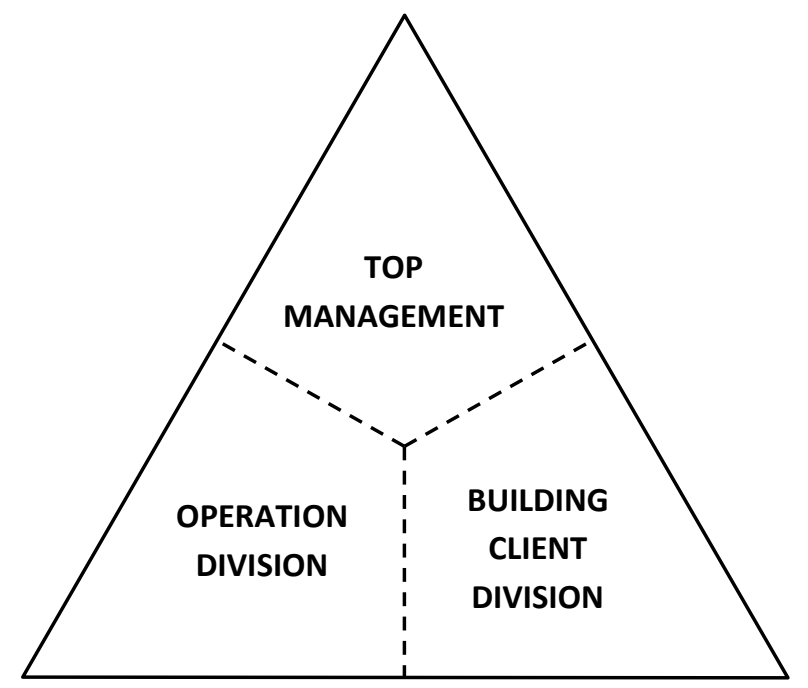

Figure 4: The building client seen as three-partite. 
1. Top Management: Managing the building portfolio, orders new facilities. Head of both building client division and operation division.

2. Building Client division: Manage the building projects on behalf of the top management.

3. Operation division: Operates and maintain existing and possibly future facilities. In the swimming facilities, operation is decentralized and located at the specific swimming facilities, while the building client and Top Management are placed centrally at the municipally. In DTU Campus Service, the Operation division is located close to Building Client division and Top Management.

The three-partite building client is recognised in a large number of public and private building projects. In cases, where one party is missing, for instance if the future operation division is not established yet, the two other parties must take care of the initiatives of the missing party, possibly by external competences like consultants.

The three parties should not be confused with the three often used terms for FM management levels; strategical, tactical and operational. As an example, the list of initiatives, which the operational division should care for, includes both initiatives on tactical and operational level.

In DTU Campus Service, and possibly in similar organisations, it is a common assumption, that the Building Client division is responsible for including operational knowledge in the building projects, since they are managing the projects. Our analysis suggests that it can be helpful to revise this assumption and acknowledge the important roles of each part in order to realize the sustainable potential of new facilities.

The 18 well-implemented initiatives in DTU Campus Service only included one of the initiatives the Operation division should take care of. It included 13 initiatives taken care of by the Building Client division and four initiatives taken care of by the Top Management. This indicates that the operational division struggles the most with implementing initiatives in DTU Campus Service. A similar picture was not found in the survey of the five swimming facilities. It was not a part of the research project to investigate reasons for the lack of well implemented initiatives in the operational division of Campus Service, but possible reasons could be lack of demand from management, overshadowing focus on operational day-to-day tasks, lack of competences, lack of resources, lack of incentives, or cultural reasons. We recommend future research to investigate this further.

\section{Four degrees of implementation}

The results of the case study and the survey shows that the majority of the initiatives are in use. However, some of the initiatives are only limited implemented or used with limited effect. This indicates that the initiatives in themselves are not sufficient, but they need to be adapted to a specific context or supported by other deliberate actions to achieve the best effects. Figure 5 illustrates that initiatives not used, not surprisingly, has no effect on the sustainability of the new facility, limited implemented initiatives has no or minor effect, whilst the well-implemented initiatives can have a high effect on realizing the sustainability potentials of the new facility. In the case study of DTU Campus Service well implemented initiatives constituted the largest category; while limited implemented initiatives made up the largest category in the survey of the swimming facility. 


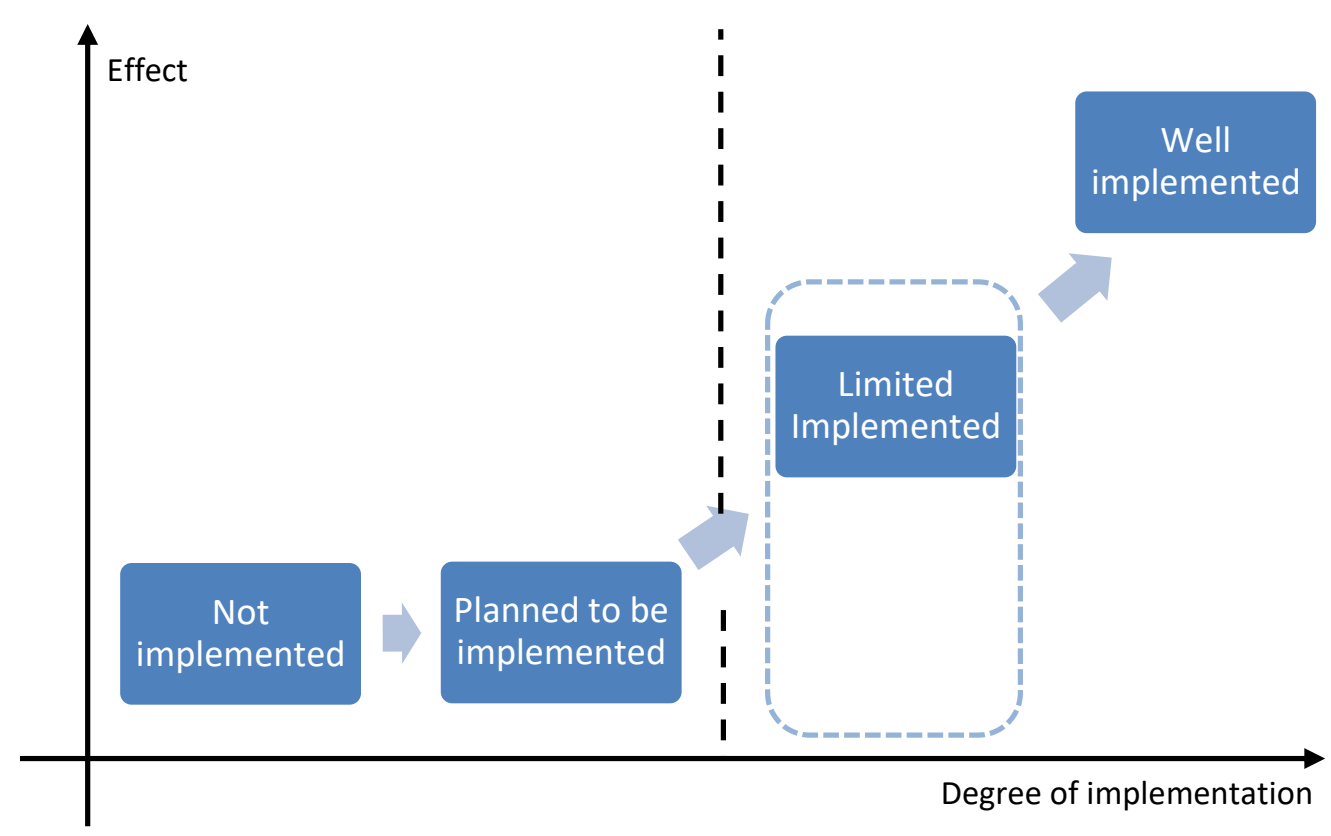

Figure 5: Impact on realizing the sustainable potential of the new building.

\section{Proposal for a revised list of initiatives}

Table 3 presents a proposal for a revised list of the originally $31+11$ initiatives to be considered in early design phases to contribute to realizing the sustainability potentials of a new facility. The initiatives are listed by whom of the three-partite building client should take care of the initiative, all though most initiatives requires contributions from more than one party. Initiatives on the original list that are regarded as very similar and overlapping have been reduced, initiatives describing demands to be included in the building brief have been gathered to one list of demands and two of the 11 additional initiatives from DTU Campus Service have been excluded as they were described as not very good.

Top Management should consider:

32 Clear statement that operational friendly and energy efficient buildings are a high priority

34 Establish a professional building client/construction management division

35 Operation Division represented in management group

36 FM considered a strategic discipline

37 Care for good relations between Building Client Division and Operation Division

Building Client Division should consider:

1 Continuous Briefing

2 Detailed Building Brief

$3 \mathrm{~A}$ Project review externally

4 Public Private Partnership (PPP)

5 Contractor responsibility for operation and maintenance

7 Technical Due Diligence

10 Use of Life Cycle Cost assessments 
A List of demands to include in the building brief (initiatives 11, 12, 13, 14, 15, 16, 17, 18, 22, 23, $24,25,26,27,28,29,30,31$ from table 1 )

39 Log deviations from the guidelines and standards for building projects (see initiative 9)

41 Establish a safety net to secure considerations of comments and demands mentioned in wrong phases

42 Care for good relations between design team, construction team and Operations Division.

19 Demand of evaluation of consequences of significant changes during the design phase on operational friendliness, energy efficiency etc.

20 Demand of evaluation of consequences of significant changes during the construction phase on operational friendliness, energy efficiency etc.

\section{Operation Division should care for:}

9 Prepare guidelines and standards for building projects

B Specifications of demands to include in the building brief

17 Specifications on demands of operation- and maintenance material from contractors (and preparations to receive documentation according to hand-over time schedule)

15 Specifications of demands of operational plan and operation budget

40 Agreements on how and what is included in internally reviews conducted by the operational staff

3B Project review internally

6 Continuously commissioning

8 Plan for when and how the right competences should be involved in the project to include operational knowledge in the project.

21 Specific demands to the operational organizations role in starting up the operation

Table 3: Initiatives organized by responsibility

\section{Discussion}

A more comprehensive and broader literature review could have resulted in more and different initiatives than the 31 initiatives considered in this study. One of the initiatives that has not been included in the study is the British concept called "Soft landings" (BSRIA, 2014). Soft landings principles are designed for building clients and their professional teams as guidance to bridge the gaps between the different stages of a building project, in particular from construction to operation and from operation to design.

Soft landings does not replace existing tools and concepts, but can be seen as a framework for the entire process. It is currently not a common practice in Denmark, but Soft landings could possibly serve to gather the fragmented use of initiatives already implemented by Danish building clients investigated in this paper. As examples, initiatives on detailed building brief, project reviews, commissioning, plan for involvement of FM personnel, demands on training of FM and users, and demands on energy consumption (initiatives 2, 3, $6,8,18,24$ in table 1) are included in the Soft landing concept (BSRIA, 2014). In our current research, we are investigating the relevance of a comprehensive framework like Soft landings.

The initiatives described in this paper include both large concepts and more simple tools. It makes it difficult to compare the use of the initiatives, as the use of one initiative, e.g. commissioning, could have same effect as the use of several simple initiatives or even cover several simple initiatives. 
The case study of DTU Campus Service added 11 initiatives not found in the literature review. Despite the limitations of the literature review, it indicates the need for more initiatives than currently provided in Danish guides and handbooks on the topic. Campus Service has developed well-implemented initiatives that could serve as inspiration for other building clients, including the swimming facilities. The survey methodology of the swimming facilities did not aim at finding additional initiatives, but possibly that could have resulted in other or similar additional initiatives. Studies of other building clients could possibly add even more initiatives.

\section{Conclusion}

Based on former research we initially identified 31 initiatives, which are expected to improve the integration of operational knowledge in building projects with the purpose of realizing the sustainability potential of new facilities and bridging the performance gap. These 31 initiatives formed the basis for both the case study of a university campus and the survey of five swimming facilities presented in this paper.

The case study and the survey showed that many of the initiatives are used. DTU Campus Service uses more initiatives than the building clients of the swimming facilities, and uses initiatives not found in literature. However, using the initiatives does not necessarily contribute to better performance of new built facilities. The paper differs between well-implemented and limited implemented initiatives. It takes deliberate effort to get the initiatives well-implemented and fully adopted in the organisation to achieve a good effect.

The building client in DTU Campus Service and the swimming facilities includes three main actors responsible for the use of the initiatives; Top Management, Building Client division and Operation division. The paper suggests that each party is responsible for a share of the initiatives, though cooperation between the three parties is a necessity. The absence of one party requires further actions from the parties present. A revised list of available initiatives based on the findings in the studies distributes the initiatives on the main actors, and serves as an overview of appropriate initiatives to realize sustainability potentials of new facilities by the different parties involved in building projects and building operation.

This study has been inductive and exploratory based on a limited review of existing literature. We have for instance not included literature on knowledge communication. In our further research, we will conduct a deeper and more systematic literature review to gain a deeper insight into knowledge management as a basis for a comprehensive empirical study of knowledge transfer.

\section{References}

Alhaji Mohammed, M. and Hassanain, M.A. (2010), "Towards Improvement in Facilities Operation and Maintenance through Feedback to the Design Team", The Built \& Human Environment Review, Volume 3. 
Bröchner, J. (1996), "Feedback for Facilities Management to Design and Construction - Systems Issues". In: Langford, A. and Retik, D.A. (Eds.): The Organization and Management of Construction, Vol. 3, Taylor \& Francis, London, pp. 238-46.

BSRIA (2014), "The Soft Landings Framework: for better briefing, design, handover and building performance in-use". The Building Services Research and Information Association. United Kingdom.

BUR (1985), "Planlægning af driftsvenligt byggeri - en anvisning". Byggeriets Udviklingsråd (The Construction Development Council: Planning of operational friendly buildings). Copenhagen.

Chew, M. Y. L., Conejos, S., and Asmone, A. S. (2017), "Developing a research framework for the green maintainability of buildings". Facilities, Vol. 35(1-2), pp. 39-63.

Corry, E., Pauwels, P., Hu, S., Keane, M., O’Donnell, J. (2015), “A performance assessment ontology for the environmental and energy management of buildings", Automation in Construction, Vol. 57, pp. 249-259.

Due, P.H., Stephensen, P. (2012), "POKI - A Management Tool for the implementation of FM know-how in Construction Project". In: Jensen, P.A. and Nielsen, S.B. (Eds.): Facilities Management Research in the Nordic Countries - Past, Present and Future. Centre for Facilities Management - Realdania Research, DTU Management Engineering, and Polyteknisk Forlag.

Emmitt, S. (2007), Design Management for Architects. Blackwell Publishing.

Erdener, E. (2003), "Linking Programming and Design with Facilities Management", Journal of performance of constructed facilities, Vol. 17(1).

Ganisen, S., Jawahar Nesan, L., Mohammad, I. S., Mohammed, A. H. and Kanniyapan, G. (2015), “Facility management variables that influence sustainability of building facilities", Jurnal Teknologi, Vol. 75(10), pp. 27-38.

Göçer, Ö., Hua, Y. and Göçer, K. (2015), "Completing the missing link in building design process: Enhancing post-occupancy evaluation method for effective feedback for building performance", Building and Environment, Vol. 89, pp. 14-27.

Hansen A. P., Damgaard T. (2012), "Communities of Practice as a Learning Challenge in Construction Projects - How FM knowledge can be integrated in the learning processes". In: Jensen, P.A. and Nielsen, S.B. (Eds.): Facilities Management Research in the Nordic Countries - Past, Present and Future. Centre for Facilities Management - Realdania Research, DTU Management Engineering, and Polyteknisk Forlag.

Jaunzens, D., Warriner, D., Garner, U. and Waterman, A. (2001), Applying facilities expertise in building design. Building Research Establishment.

Jensen, P.A. (2002), Byggeri - fra vision til ny virkelighed. (Building - from vision to a new reality). Forlaget Tegl.

Jensen, P.A. (2008), Facilities Management for Practitioners and students. Centre for Facilities Management - Realdania Research, DTU Management Engineering. 
Jensen P.A. (2009), "Design Integration of Facilities Management", Architectural Engineering and Design Management, Volume 5, Issue 3, pp. 124-135.

Jensen, P.A. (2011), Håndbog i Facilities Management (Handbook on Facilities Management). 3. extended edition. Danish Facilities Management Association (Dansk Facilities Management - netværk).

Jensen, P.A. (2012), "Knowledge transfer from facilities management to building projects: A typology of transfer mechanisms", Architectural Engineering and Design Management, Vol. 8, No. 3, pp. 170-179.

Kalantari S., Mardelle M. Shepley, Zofia K. Rybkowski and John A. Bryant (2017), "Collaboration between designers and facility managers: comparing the United Kingdom, the United States, and the Middle East", Facilities.

Lê, M.A.T. (2007), "Linking experience and learning: Application to multi-project building environments." Engineering, Construction and Architectural Management, Vol. 14, No. 2, pp.150-163.

Meng, X. (2013), "Involvement of facilities management specialists in building design: United Kingdom experience". Journal of Performance of Constructed Facilities, Vol. 27(5), 500-507.

Ornetzeder, M., Wicher, M. and Suschek-Berger, J. (2016), "User satisfaction and well-being in energy efficient office buildings: Evidence from cutting-edge projects in Austria", Energy and Buildings, Vol. 118, pp. 18-26.

Galamba, K. R. and Nielsen, S. B. (2016), "Towards sustainable public FM: collective building of capabilities". Facilities, Vol. 34, No. 3/4, pp. 177-195.

Saunders, M., Lewis, P. and Thornhill, A. (2016), Research methods for business students. Seventh Edition. Pearson Educational Limited.

Værdibyg (2013), Driftsorienteret byggeproces. (ValueBuild: Operational oriented building process, Værdiskabende byggeproces. (http://www.vaerdibyg.dk).

Way, M. and Bordass, B. (2015), “Making feedback and post occupancy evaluation routine 2: Soft landing involving design and building teams in improving performance", Building Research and Information, Vol. 33, No. 4, pp. 353-360.

Wilde, P. (2014), "The gap between predicted and measured energy performance of buildings: A framework of investigation", Automation in Construction, Vol. 41, pp. 40-49.

Zuo, M., Zhao, D. and Gao, P. (2013), "Models for Describing Knowledge Transfer Mechanisms", Scientific Journal of Management Science and Engineering, Vol. 3, Issue 3, pp. 63-72. 